\title{
WNT Sinyal Yolağı ve Kanser
}

\author{
Buket ALTINOK ${ }^{1}$, Asuman SUNGUROĞLU ${ }^{2}$ \\ ${ }^{1}$ Ankara Üniversitesi Sağllk Hizmetleri Meslek Yüksekokulu, Ankara, Türkiye \\ ${ }^{2}$ Ankara Üniversitesi Tıp Fakültesi Tıbbi Biyoloji Anabilim Dalı, Ankara, Türkiye \\ E-mail: baltinok@ankara.edu.tr
}

\begin{abstract}
Özet
Wnt sinyal yolağı kök hücre biyolojisinde, doku ve organ rejenerasyonunda ve homeostatik devamlılığın sağlanmasında kritik bir öneme sahiptir. Bu yolağın anormal aktivasyonunun pek çok tümör tipinin gelişiminde anahtar bir rol oynadığı ve bu durumun kanser kök hücrelerin $(\mathrm{KKH}$, cancer stem cell=CSC) davranışını etkilediği bilinmektedir. KKH'ler ilaca direnç gösterebilme özelliğinden dolayı hastalıkların nüks etmesinin temel nedeni olduğu düşünülmektedir. Wnt sinyal yolağını hedef alan yeni terapötik ilaçların keşfedilmesi, KKH'lerin elimine edilmesine ve kanserin yok edilmesine yönelik yeni umutlar vaat etmektedir. Bu derleme de Wnt sinyal yolağı, bu yolağın kanser kök hücre kavramı ile ilişkisi ve klinik uygulamalarını hedef alan yakın zamandaki terapötik yaklaşımlar tartışılmıştır.
\end{abstract}

Anahtar kelimeler: Wnt sinyal yolağı, kanser kök hücre, terapötik ilaçlar

\begin{abstract}
Wnt signaling pathway is critically important in stem cell biology, both in homeostatic maintenance and regeneration of tissues and organs. Aberrant activation of this pathway has been described as a key player in the development of a wide array of tumor types, via affecting the behavior of Cancer Stem Cells (CSCs). CSCs are believed to be responsible for disease relapse, as they possess drug-resistance properties. The development of new therapeutic drugs targeting this pathway to promise new hope to eliminate CSCs and achieve cancer eradication. We review the Wnt signaling pathway, the relationship between this pathway and CSC term and recent therapeutic approaches to target this pathway and their clinical applications.
\end{abstract}

Keywords: Wnt signaling pathway, cancer stem cell, therapeutic drugs 


\section{Giriş}

Kanserde gözlenen remisyon oranlarında son yıllarda önemli gelişmeler olmasına rağmen kanser tedavisine yönelik halen çok çeşitli engeller mevcuttur. Tedaviye direnç gelişimi, hastalığın yeniden nüks etmesi ve metastaz ile ilişkilendirilmekte olup bunlar kanserde majör problemler olarak karşımıza çıkmaktadır. Kanser hücrelerinin bir alt kümesi olan kanser kök hücre (KKH) ya da kanser başlatıcı hücre (cancer initiating cell=CIC) popülasyonları bu problemlerle ilişkilendirilen anahtar oyunculardır. KKH tanımı, normal somatik kök hücreler (SKK, somatik stem cell=SSC)'in kendi kendini yenileyebilme (self renewal) ve pluripotensi özellikleri ile benzer özellikler göstermektedir. "Self renewal" ana hücrenin benzeri en az bir yavru hücre oluşturmak üzere kendini yenileyebilme kabiliyeti olarak tanımlanmakta olup, kök hücrelerin pluripotensi özelliği ise bu hücrelerin pek çok özelleşmiş hücre tipine farklılaşmasına izin vermektedir. KKH, genetik değişimler ve mikroçevresel faktörlerin varlığ1 sonucunda etkilenmiş doku ya da organ sisteminde normal somatik kök hücrelerden ortaya çıkmıştır ve kanserin başlamasından sorumlu tutulan bir faktör olduğuna inanılmıştır (Reya vd 2001).

Son yıllarda kanser araştırmalarında en çok KKH popülasyonunu karakterize etmek üzerine çalışmalar yapılmış ve en önemlisi KKH'lerin kendini yenileyebilme ve farklılaşabilme özelliklerini düzenleyen majör yolaklar tanımlanmış ve normal somatik kök hücrelere zarar vermeden KKH'ler tedavi amaçlı hedeflenmiştir. Somatik kök hücreler gibi KKH özellikleri de, korunmuş bu yolaklar (Notch, Hedgehog, Wnt/ $\beta$-catenin) tarafindan yönetilmektedir (Duchartre Y vd 2016).

$\mathrm{Bu}$ derlemede Wnt sinyal yolağı üzerinde yakın zamanda yapılan çalışmalar, kanser gelişimi ve ilaç direnci üzerindeki rolleri ve bu yolağı hedef alan yeni terapötik bileşiklerin keşfinin anlatılması amaçlanmıştır.

\section{Kanser Kök Hücre Kavramı ve Kanser Oluşumundaki Rolleri}

Son 10 yılda kanser kök hücre kavramı yeniden ortaya çıkmış ve bu alanda pek çok çalışmaya öncülük etmiştir. Yakın zamanda ortaya çıkan gelişmeler KKH varlığı ve pek çok kanser türündeki rolleri hakkındaki şüpheleri minumuma indirmiştir. Bununla birlikte bu hücrelerin kökeni ile ilgili olarak iki alternatif teori ortaya atılmıştır. Bunlardan ilki majör sinyal yolaklarının aktivasyonuna öncülük eden tümör yığınını oluşturan kanser hücrelerinde meydana gelen bir genetik değişiklik sonucu oluştuğudur. Bir diğeri ise normal somatik kök hücrelerde meydana gelen kazanılmış mutasyonlar sonucu somatik kök hücrelerin KKH'ye transforme olduğudur. KKH tümör hücrelerine proliferasyon, telomeraz aktivitesi ve "self renewal" özellikleri kazandıran, tümör yığını içerisinde seyrek popülasyon olarak tanımlanan hücre grubudur. KKH'lerin klasik tedavi yöntemlerine (kemoterapi, radyoterapi) direnç gösterdiği, kanserin nüks etmesinden ve metastazından sorumlu olduğu bilinmektedir. İstirahat halinde bulunması (sessiz faz) ve kendi mikroçevresi ile olan spesifik interaksiyonları KKH'lerin ilaca direnç gösterme özelliklerinde önemli birer rol oynar. Bütün bu özellikler KKH'nin kanser oluşumundan, gelişiminden, ilaca direnç göstermesinden ve nüks etmesinden sorumlu olduğunu düşündürmektedir (Duchartre Y vd 2016).

KKH'nin tümör oluşturma özellikleri, ilk kez Dick ve arkadaşları tarafından CD34+38- belirteçleri ile akut miyeloid lösemide (AML) tanımlanmıştır. Bu lösemik kök hücreler (LKH, Leukemic Stem Cells=LSC) kanser kök hücrelerin "self renewal" özelliklerine ve pluripotensi kabiliyetine sahip olup, 
löseminin oluşumuna öncülük etmektedir (Jamieson vd 2004). Fakat LKH popülasyonunun dışında LKH olmayan bir grup hücre grubu daha ortaya çıkmıştır.

Yakın zamanda yapılan çeşitli çalışmalarda KKH'nin birçok tümör tipinin (beyin, melanoma, meme, karaciğer, pankreas ve kolon kanseri) gelişimiyle ilişkili olduğu gösterilmiştir (Duchartre Y vd 2016).

\section{Embriyonik gelişim sürecinde Wnt Sinyal Yolağı}

Wnt sinyal yolağı embriyonik gelişim ve normal yetişkin homeostasisi için çeşitli temel süreçlerde rol oynar. Wnt ailesinin ilk üyesi olan "Int-1" farede bir proto-onkogen olarak keşfedilmiştir. Bu keşifden 5 y1l sonra Drosophila'da bulunan "wingless" geninin int-1 geni ile dizi ve fonksiyon benzerliği gösterdiği saptanarak bu genin homoloğu olduğu bulunmuştur. Daha sonra bu iki gen ismi birleştirilmiş ve literatüre Wnt geni olarak geçmiştir (Nusse ve Varmus 1992, Nusse 2005). Günümüze kadar insanda tanımlanmış olan Wnt gen ailesine ait birbirine temel yapı olarak benzeyen 19 adet protein vardır ve bunlar reseptörlerine bağlanmada önemli rol oynayan sistein'den zengin bölgeler içeren, glikoprotein yapısında, ekstrasellüler bölgeye salınan, sinyal yolu uyarıcılarıdır (Ilyas 2005). $\mathrm{Bu}$ sinyal yolağının hücre proliferasyonu, sağ kalım, kendi kendini yenileme ve farklılaşma gibi pek çok hücresel süreçte önemli rol oynadığı gösterilmiştir (Willert ve Jones, 2006; Schambony ve Wedlich, 2007). Bu yolağın keşfinden hemen sonra bu yolağa ait mutasyonların ve çeşitli fonksiyon bozukluklarının belirlenmesi ile bu yolak, çeşitli hastalıklarla (Tip II diyabet, Parkinson, Alzeheimer, hepatokarsinom, kolon kanseri, lösemi) ilişkilendirilmiştir (Duchartre Y vd 2016).

Wnt/ $\beta$-katenin (Kanonik/Klasik), Wnt/Ca ${ }^{+2}$ (Kanonik olmayan) ve Wnt/Planar Hücre Polaritesi (PCP) (Kanonik olmayan) olmak üzere 3 çeşit Wnt sinyal yolağı tanımlanmıştır (Huelsken ve Behrens 2002).

Wnt/ $\beta$-katenin sinyal yolağında, Wnt ligandının Frizzled (Fz) reseptörüne ve Fz'nin ko-reseptörü olarak tanımlanan düşük yoğunluklu lipoprotein reseptör ilişkili protein olan LRP5/6 proteinine bağlanması ile birlikte hücre içi sinyalizasyon başlar. Böylelikle Wnt sinyal mekanizmasının başlatılabilmesi için gerekli olan üçlü yapı (Fz-Wnt-LRP5/6) birbirleriyle bağlantı kurmuş olur (Nusse ve Varmus 1992, Mikels ve Nusse 2006, Cadigan ve Liu 2006, Chen vd 2008) (Şekil 1). Bu bağlanmanın sonrasında sinyal önce sitoplazmaya geçer ve DVL (dishevelled) fosforilasyonu uyarılır. Daha sonrasında bu fosforilasyon Axin, APC (adenomatous polyposis coli), CK1 (casein kinase 1) and GSK-3 (glycogensynthase kinase 3 )'den oluşan yıkım kompleksini dağıtarak, $\beta$-katenin stabilizasyonunu sağlar ve $\beta$-kateninin nükleer translokasyonuna izin verir. Çekirdeğe giren $\beta$-katenin, transkripsiyon faktör ailesi olan TCF/LEF (T-cell factor/lymphoid enhancer factor) üyelerine bağlanarak, koaktivatörlerinde yardımıyla birlikte (p300 ve CBP (CREB-binding protein) hücrenin proliferasyonunu sağlayacak çok sayıda Wnt hedef geninin transkribe olmasını sağlar (Veeman vd 2003; Mosimannet vd 2009; Moon, 2005; Teo ve Kahn, 2010).

Wnt ligandının yokluğunda sitoplazmik $\beta$-katenin yıkım kompleksi tarafından parçalanmak üzere hedef alınır. CK1 ve GSK3 komponentleri $\beta$-katenini, $N$ terminal bölgesindeki serin ve treonin rezidülerinden fosforlar. Fosforlanan $\beta$-katenin, transducin tarafindan tanınır ve tranducin $\beta$-kateninin proteozomal yıkımına öncülük eder (Kimelman ve Xu, 2006) (Şekil 1). 


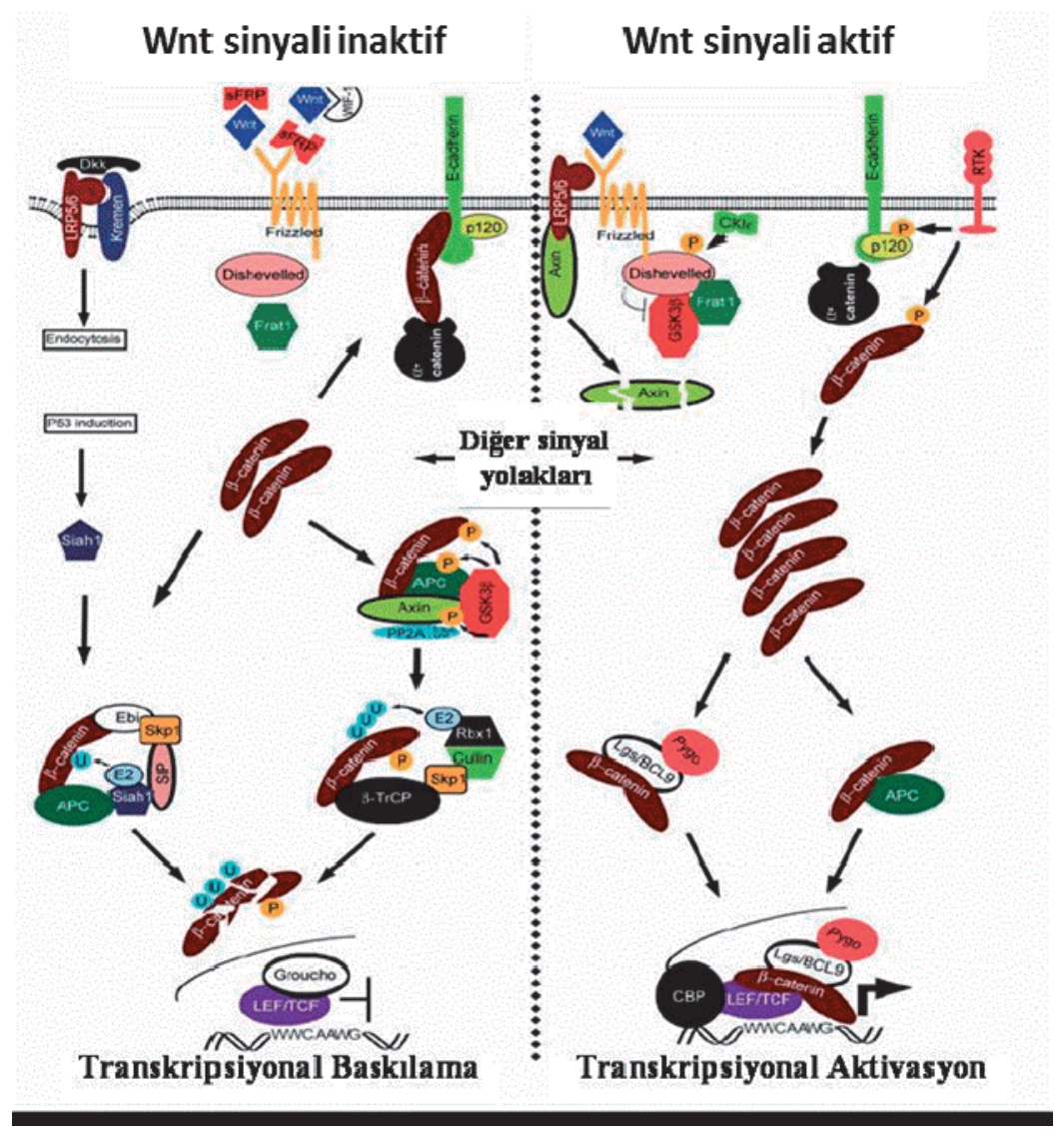

Şekil 1: Wnt/ $\beta$-Katenin (Kanonik) Yolağı (Ilyas 2005)

Wnt/ $\beta$-katenin sinyal yolağı haricinde kalan diğer 2 yolak ise " $\beta$-katenin'den bağımsız sinyal yolakları" olarak isimlendirilir. $\mathrm{Bu}$ yolaklar farklılaşma, hücre polaritesi ve migrasyonla ilişkilendirilmiştir.

Kanonik olmayan Wnt/Planar Hücre Polaritesi (PCP) yolağında, Wnt ligandları Fz reseptörlerine bağlandığı zaman RhoA (Ras homolog gene family member A), RAC (Ras-related C3 botulinum toxin substrate) ve Cdc42 (cell division control protein 42) gibi GTPazlar aktive olur (Lai vd 2009). PCP yolağ1 hücre iskeletini etkiler ve hücre adezyonundan sorumlu hedef genlerin transkripsiyonel aktivasyonunu uyarır (Yamamoto vd 2008) (Şekil 2).

Kanonik olmayan $\mathrm{Wnt} / \mathrm{Ca}^{+2}$ yolağında ise, Wnt ligandları Fz reseptörlerine ya da alternatif reseptörlere (RYK ya da ROR) bağlandığı zaman hücre migrasyonunu ve Wnt/ $\beta$-katenin yolağının inhinisyonunu hücre içi $\mathrm{Ca}^{+2}$ akışı ve kalmodulin kinaz II (CaMK2), Jun kinaz (JNK) ve PKC aktivasyonu boyunca artırır (Van ve Nusse, 2009) (Şekil 2). 


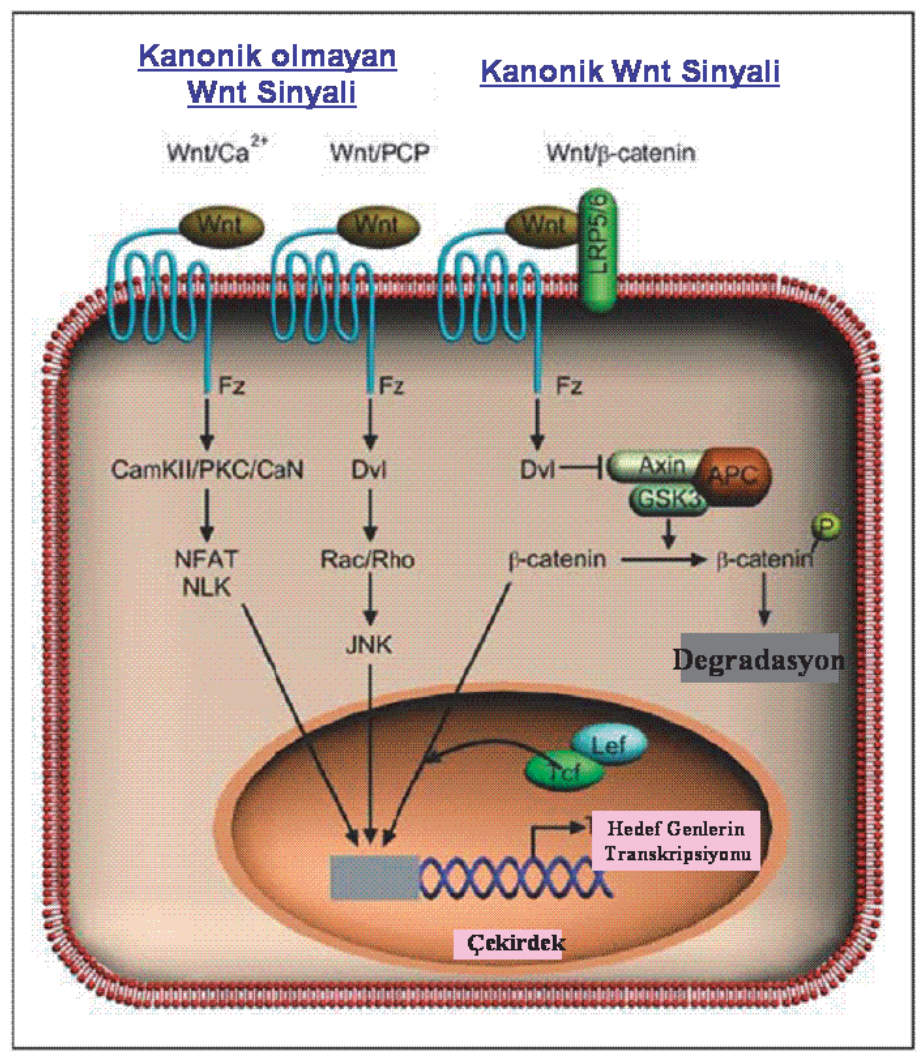

Şekil 2: Wnt Sinyal İleti Yolaklarl (Espada vd 2009)

\section{Kanser Kök Hücresinde Wnt Sinyalinin Rolü}

Wnt sinyalinin anormal aktivasyonu lösemik kök hücrelerin oluşumu ve devamlılı̆̆ ile ilişkilendirilmiştir. Kök hücre homeostasisindeki Wnt sinyalinin önemi şaşırtıcı bir durum değildir (Klaus ve Birchmeier, 2008). Çünkü kanser kök hücre gelişiminde anormal Wnt sinyal aktivasyonuna pek çok örnek verilebilir. Kronik Miyeloid Löseminin (KML) kronik fazından blastik kriz fazına geçişte GMP (Granülosit-makrofaj progenitör hücreleri) hücrelerindeki GSK3 $\beta$ mutasyonları ve $\beta$ katenin stabilizasyonu öncülük eder (Abrahamsson vd 2009). Yakın zamanda yapılan bir çalışmada, KML kök hücrelerinde Wnt sinyal yolağı üzerine tirozin kinaz inhibitörünün (TKI) baskılayıcı etkisi olmasına rağmen bu hastalarda Wnt yolağının yeniden aktive olmasıyla birlikte hastalarda relapsların meydana geldiği gösterilmiştir (Riether vd 2015). TKI ile tedavi CD70 promotor metilasyonuyla ilişkili olarak miR29'un ifadesini azaltmıştır. CD70'in yüksek düzeyde ifade olması, Wnt sinyal yolağının bir aktivatörü olarak bilinen CD27'nin transkripsiyonunu artırdığı bilinmektedir (Schurch vd 2012). Wang ve arkadaşları AML lösemik kök hücrelerinde $\beta$-katenin ifadesi ile birlikte Wnt sinyalinin anormal şekilde aktive olduğunu göstermişlerdir (Wang vd 2010). Bu çalışmada anormal Wnt sinyal yolağı aktivasyonunun sadece hematopoetik kök hücrelerden değil progenitör hücrelerden de lösemik kök hücre oluşumuna neden olduğunu düşündürmüştür. Yakın zamanda B-ALL (B-hücreli akut lenfoblastik lösemi) hücrelerinin tedavisinde kullanılan küçük moleküller $\beta$-katenin ve koaktivatör olan CBP'nin arasındaki interaksiyonu inhibe etmiştir (Gang vd 2014). Böylelikle bu durum hücrelerin farklılaşmaya gitmesiyle ve "self renewal" kaybıyla sonuçlanmıştır. ICRT14, $\beta$ katenin-TCF interaksiyonunu bozan bir inhibitör olup Wnt hedef genlerinin ifadelerinde azalmaya yol 
açmaktadır. ICRT14, kemoterapi ile kombine tedavi şeklinde uygulandığ zaman ALL hücrelerinin yaşama yüzdesini düşürdüğü ve tedaviye dirençli hastaları ilaca duyarlı hale getirdiği literatürde gösterilmiştir (Dandekar vd 2014).

Araştırmacılar KKH'leri hedef almak amacıyla bu hücreleri tanımlayabilecekleri yollar üzerine odaklanmışlardır. Normal SKH ve KKH genellikle benzer hücre yüzey belirteçlerini eksprese ederler (Klonisch vd 2008). Yapılan çalışmalarda meme kanserinde spesifik belirteçler eksprese eden kanser kök hücre benzeri hücreler karakterize edilmiştir. Bu hücreler CD44 yüzey belirtecini yüksek, CD24 yüzey belirtecini düşük eksprese etmişlerdir (Al-Hajj vd 2003). Hem CD44 hem de CD24 hücre yüzey belirteçleri Wnt hedef genleridir (Han vd 2012, Ahmed vd 2010, Shulewitz vd 2006). CD44, LRP6 aktivitesi üzerinden Wnt sinyal yolağının pozitif regülatörü olarak görev yapar (Shulewitz vd 2006, Schmitt vd 2015). Ayrıca hücre yüzeyinde $\beta$-katenin ile bağlantılı halde bulunan E-kaderinin düşük düzeyde ifade olması $\beta$-kateninin nükleer translokasyonunu ve Wnt sinyal aktivasyonunu uyarır (Huels vd 2015). Bunlara ek olarak çok sayıda Wnt/ $\beta$-katenin hedef geni invazyon, migrasyon ve metastazla (S100A4, fibronektin, L1CAM, CD44, MMP7, uPAR vb) ilişkilendirilmiştir (Brabletz vd 2005).

Wnt sinyalinin KKH'lerin kemoterapiye direnç geliştirmesinde önemli bir role sahip olduğu bilinmektedir. Kolorektal kanserlerde ilaca dirençten sorumlu ABCB1/MDR-1 geninin promotor bölgesinin çeşitli TCF bağlanma bölgeleri içerdiği literatürde belirtilmiştir (Yamada vd 2000).

Wnt sinyalinin anormal aktivasyonu epigenetik düzeyde de gerçekleşebilmektedir. Örneğin çeşitli Wnt sinyal yolağ1 inhibitörlerinin (SFRP, DKK ve WIF-1) ALL ve AML'de hipermetile olduğu bulunmuştur (Valencia vd 2009).

\section{Wnt Sinyali ve Hematopoetik Kök Hücre Nişi}

Hematopoetik kök hücreler "mikroçevre", diğer adıyla "hematopoetik niş"den gelen iç ve dış sinyallerle sık1 bir şekilde kontrol edilir (Boulais ve Frenette 2015). Bu niş ortamı çeşitli hücre tiplerinden oluşur (osteoblast, osteoklast, endotelyal hücreler, mezenkimal kök hücreler vb). Yapılan geniş kapsamlı araştırmalara göre HKH ve LKH üzerine mikroçevrenin ve Wnt ligandlarının rollerinin tam olarak anlaşılamadığı belirtilmiştir (Luis vd 2012, Lane vd 2011). Bazı çalışmalarda kanonik Wnt sinyal yolağının HKH sessizliğinde ve "self renewal" devamlılığında kritik bir role sahip olduğu gösterilmiştir. Wnt sinyal yolağ1 inhibitörü Dkk1 (Dickkopf1)'in özellikle osteoblastlarda ifade olması; HKH'lerde Wnt sinyal aktivasyonunun azalmasına ve HKH kök hücre özelliklerini (kontrolsüz çoğalma, bölünme vb.) kaybetmesine öncülük eder (Fleming vd 2008). Buna karşın stromada Wnt sinyal aktivasyonu Notch ligand salgılanmasını uyararak, HKH'lerin "self renewal" özelliğini aktive eder (Kim vd 2009, Ahn vd 2010). Bununla birlikte diğer araştırmacılara göre yetişkin fare modellerinde hematopoezin düzenlenmesinde kanonik Wnt sinyal yolağının rol oynamadığı düşünülmüştür (Kabiri vd 2015). Bunların aksine hematopoetik sistemde $\beta$-kateninin yüksek seviyede ifade olması HKH havuzunun devamlılığının bozulmasında ve miyeloid, lenfoid hücre kompartmanlarının farklılaşmalarında rol oynayabileceğini gösteren çalışmalarda mevcuttur (Kirstetter vd 2006). Böylelikle lösemi çalışmalarına bakılacak olursa, Wnt sinyalinin lösemi üzerine farklı etkilerinin olduğu görülmektedir.

Zhang ve arkadaşları Kronik Miyeloid Lösemide mikroçevrenin (mezenkimal kök hücreler (MKH)) apoptozu azaltarak imatinib ile tedavi edilen KML lösemik kök hücre ya da progenitörlerinin kemik 
iliğinde yerleşerek engraftment özelliğini geliştirdiğini göstermişlerdir. Bu koruyucu etki lösemik hücrelerin N-kaderin boyunca MKH ile direkt interaksiyonunu sağlayarak $\beta$-katenin stabilizasyonu sayesinde Wnt sinyal yolağı aktivasyonunu uyarmıştır (Zhang vd 2013). Bu buluşların desteklenmesinde, Heidel ve arkadaşları (2012) $\beta$-katenin inhibisyonunun imatinibe direnç gösteren KML LKH'lerin hedeflenmesine olanak sağladığını göstermiştir. Bununla birlikte Wnt sinyalinin Dkk1 inhibitörü tarafından inhibisyonun AML lösemik kök hücre ya da progenitörlerinin "homing" adı verilen kemik iliğine yerleşmelerinin engellenmediği gösterilmiş olup, $t(9 ; 11)$ translokasyonunun lösemi gelişimine neden olacak Wnt sinyalinin uyarılması için yeterli olduğu literatürde belirtilmiştir (Lane vd 2011).

Mikroçevre/niş ortamı hastalığın başlaması ya da lösemik kök hücre proliferasyonu ve ilaça direnç gelişmesi gibi pek çok yolda içerilmektedir (Manabe vd 1992, Meads vd 2009). Bu durum mikroçevreyi çok güçlü yeni bir hedef haline getirmiş̧ir. Buna rağmen mikroçevrenin rolü tam olarak anlaşılamamıştır. Kode ve arkadaşları (2015) AML'nin başlamasında osteoblastların temel rolünün Wnt ve FoxO1 genlerinin ekspresyonları olduğunu göstermişlerdir. Yakın zamanda Bowers ve arkadaşları (2015) tarafından kemik iliği mikroçevresinin HKH homeostasisinde ve lösemi gelişimindeki önemi gösterilmiştir. Bu çalışmaya göre, osteoblast kaybı normal kök hücrelerin sessizliğini ve "self renewal" özelliklerini bozmaktadır. Literatürdeki bütün sonuçlar birlikte değerlendirildiğinde mikroçevre, lösemik kök hücreler için Wnt sinyal yolağı üzerinden iyi bir hedef olarak düşünülmektedir. Bununla birlikte löseminin oluşumunda, devamlılı̆̆ında mikroçevrenin rolünün tam olarak anlaşılabilmesi için daha başka çalışmalara ihtiyaç duyulmaktadır.

\section{Wnt İnhibitörleri: Biyoloji ve Kliniği}

Wnt sinyal yolağının keşfinden yıllar sonra, Amerikan gıda ve ilaç dairesi (FDA= US Food and Drug Administration) tarafından onaylanmış Wnt sinyal yolağını hedef alan birkaç molekül tanımlanmıştır. FDA onaylı moleküllerden bazıları non-steroid, anti-inflamatuar ilaçlar (NSAIDS) ya da vitamin türevi ürünler olup antikanser etkiler (DuBois vd 1996, De vd 2015) (özellikle Wnt bağımlı kanserler (kolorektal kanser)) göstermektedir (Smalley ve DuBois 1997, Thun vd 2002). Örneğin siklojenazlar (COX1 ve 2), araşidonik asidi prostoglandinlere metabolize ederler. $\mathrm{Bu}$ durum $\beta$-kateninin stabilizasyonuna ve kanonik Wnt sinyal aktivasyonuna öncülük eder (Castellone vd 2005, Brudvik vd 2011, Jansen vd 2015). NSAIDS (aspirin, sulindak ya da COX inhibitörleri celecoxib gibi) tarafindan COX inhibisyonu prostoglandinlerin sentezini baskılar ve böylelikle Wnt sinyali baskılanır. NSAIDS, Wnt/ $\beta$-katenin sinyal yolağı aktivasyonu bozulan ailevi kolon polipozisli (FAB) fare modellerinde polip sayısını azaltabilme yeteneğine sahiptir (Steinbach vd 2000, Yang vd 2003). FAB hastaları 6 ay boyunca NSAID sulindak ile tedavi edildiği takdirde nükleer $\beta$-katenin düzeylerinde ve polip oluşumunda azalma gözlendiği yapılan çalışmalarda gösterilmiştir (Boon vd 2004, Baron vd 2003, Sandler vd 2003, Phillips vd 2002). Aspirin türevi NO-ASA, $\beta$-katenin/TCF kompleksini bozarak in vitro ve in vivo ortamda normal bağırsakta toksik bir etki gözlenmeksizin polip oluşumunda azalmaya neden olarak diğer çalışmalarla benzer etki göstermiştir (Williams vd 2001, 2004) (Şekil 3).

Vitamin A metabolizması sonucu üretilen Retinoidler'de kısmen Wnt sinyal yolağı inhibisyonunu sağlayarak antikanser etkiler göstermektedir (Xiao vd 2003). Vitamin D'nin aktif formu 1 $\alpha, 25$ dihidroksi-vitamin D3, tümör supresör bir etki göstererek, $\beta$-katenin ile transkripsiyonel bir kompleks oluşturur ve E-kaderin ifadesini artırır. Bu etki meme ve kolon kanserlerinde $\beta$-kateninin sitoplazmada kalmasını sağlayarak, çekirdeğe girişini engelleyerek Wnt yolağının inhibisyonuyla sonuçlanır 
(Palmer vd 2001). FDA onaylı non-spesifik Wnt inhibitörlerinin yanında çeşitli moleküler hedefe yönelik ajanlar da geliştirilmiştir ve klinik denemelerde kullanıma girmeye başlanmıştır. Kanonik Wnt sinyal yolağının anahtar moleküllerden biri olan Dvl'ye, çok sayıda çalışmada odaklanılmış ve bu proteine özgü çeşitli inhibitörlerin gelişmesine olanak verilmiştir. Dvl'nin PDZ bölgesi Dvl-Fz reseptör interaksiyonunda ve Wnt sinyalinde esas rol oynar. Bu PDZ domainini hedef alan bazı inhibitörler (NSC 668036, FJ9, 3289-8625) tanımlanmıştır (Şekil 3) ve in vivo ortamda Wnt yolağını inhibe etme kapasitesi gösterilmiştir (Grandy vd 2009).

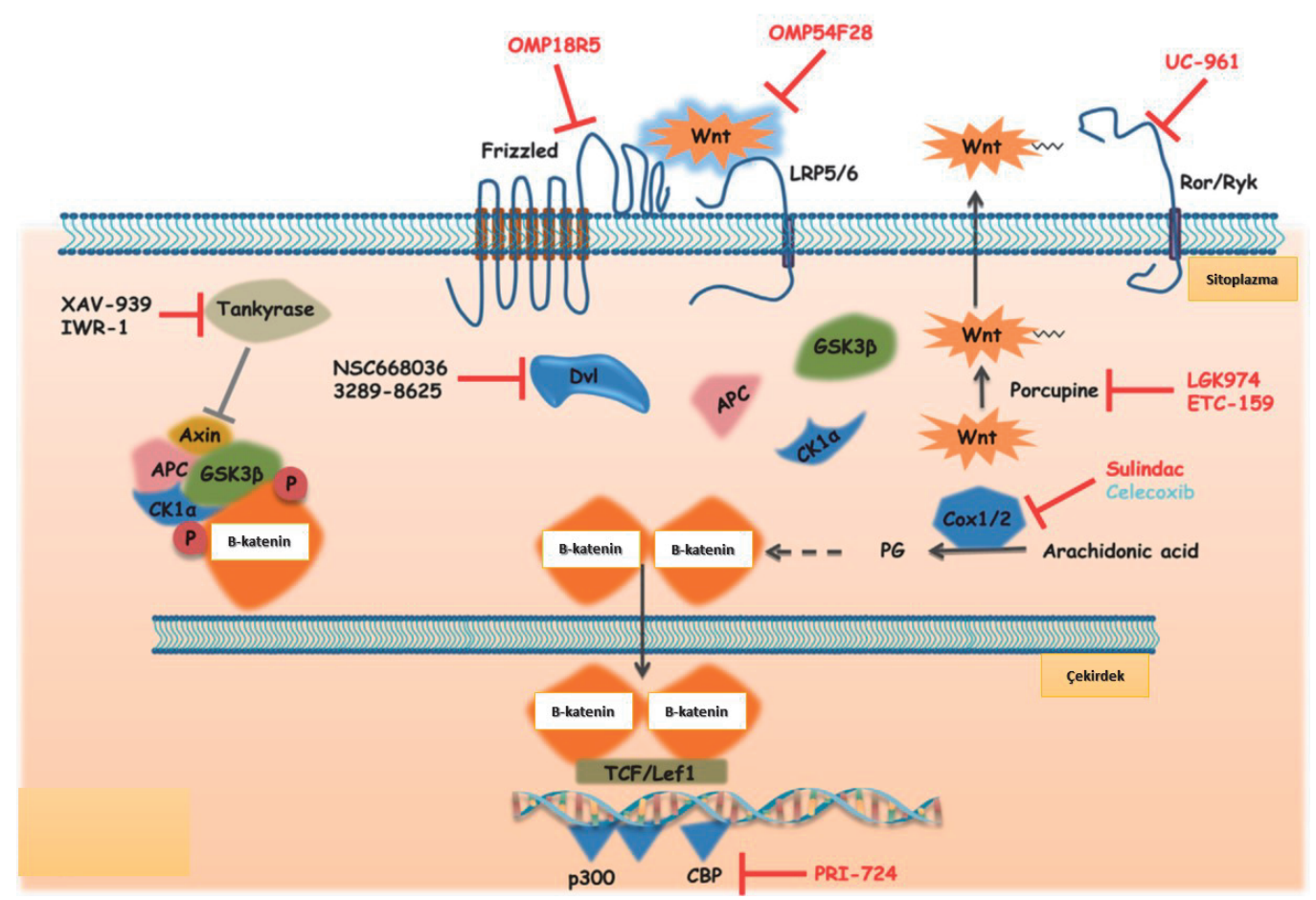

Şekil 3: Klinik çalışmlarda kullanılan Wnt inhibitörleri (Duchartre Y vd 2016)

Wnt yolağının anahtar basamaklarını inhibe edebilecek bazı bileşikler de dizayn edilmiştir. LGK974 (porcupine, PORCN inhibitörü) 2011 yılında faz I klinik çalışmalarında kullanılmaya başlanmıştır (Novartis, NCT01351103). Porcupine, membrana bağlı O-asetiltransferaz (MBOAT) ailesinin bir üyesi olup, Wnt'nin lipit modifikasyonundan ve salgılanmasından sorumludur (Kadowaki vd 1996, Rios-Esteves ve Resh 2013). ETC-159 bir PORCN inhibitörü olup, faz I klinik çalışmalarında kullanılmaktadır. 2015 yılının Haziran ayında ilk hastaya belirli dozda ETC-159 uygulanmış ve ETC159 Wnt salgılanmasını ve aktivitesini inhibe etmiştir. Bu ilaç farklı kanser türlerinde klinik öncesi denemelerde yüksek etki göstermiştir (Madan vd 2015). XAV-939 ve IWR-1 inhibitörleri (Tankyrase inhibitörleri) axin stabilizasyonunu sağlar ve $\beta$-kateninin degradasyonunu uyarır (Huang vd 2009). Telomer kısalmasından sorumlu tutularak anti-kanser ilaçlar gibi görev yapar (Kulak vd 2015).

Birçok ajan klinik denemelerde kullanılmış ve bu ajanlardan 2 tanesi 5 farklı Fz reseptörüne karşı dizayn edilmiştir. Klinik öncesi çalışmalarda kullanılan bu ajanlardan ilki OMP-18R5 olup, çeşitli insan tümör modellerinde (akciğer, pankreas, meme ve kolon) antiproliferatif etkileri gösterilmiştir (Gurney vd 2012). Faz 1 çalışmalarının sonuçlarına göre, Wnt yolağının aktivasyonundan sorumlu genlerin ifade düzeyleri azalmış ve farklılaşmadan sorumlu genlerin ifade düzeyleri artmıştır (Smith vd 2013). Bu bileşik şuan faz 1 çalışmalarında solid tümörlerde (meme, akciğer ve pankreas 
kanserleri) standart kemoterapi ile kombine tedavi şeklinde kullanılmaktadır. 2. ajan olan OMP54F28, insan Fz8 reseptörünün bağlanabileceği ekstraselüler ligand bağlanma domaini içeren rekombinant bir füzyon proteinidir (Le vd 2015). Bu bileşik Fz8 reseptör ligandlarına bağlanarak Wnt sinyalini inhibe eder. Klinik öncesi çalışmalarda OMP- 54F28'in tek başına ve diğer kemoterapötik ajanlar ile birlikte tümör büyümesini ve KKH sıklığını azalttığı gösterilerek anti-kanser etkisi kanıtlanmıştır.

\section{Sonuç}

Wnt/ß-katenin sinyal yolağının anahtar rolü kök hücrelerin ve kanser kök hücrelerin "self renewal" ve farklılaşma özelliklerinin düzenlenmesidir. Bu yolağın anormal aktivasyonu çeşitli tümör tipleri ile ilişkilendirilmiş ve böylelikle bu yolağın elemanları anti-kanser terapötikler için iyi birer hedef olarak kullanılmaya başlanmıştır. Son 5 yılda Wnt sinyal yolağının değişik basamaklarını hedef alan ajanlar (Wnt salgılanması, sinyal transdüksiyonu ya da $\beta$-katenin transkripsiyonel aktivitesi) geliştirilmiş ve bu ajanlar klinik çalışmalara yavaş yavaş girmeye başlamıştır. Wnt/ $\beta$-katenin yolağ ile ilişkili hastalıklar için etkili tedavi yolları bulabilmek amacıyla bu yolağın kendisi ve diğer yolaklarla ilişki halinde bulunan mikroçevreyi kapsayan ağ üzerinde çalışmalar halen devam etmektedir. Gelecekteki çalışmalar Wnt sinyal yolağının yeni hedef genlerinin keşfine ihtiyaç duymaktadır.

\section{Kaynaklar}

Ahmed, M.A., et al., 2010. CD24 is upregulated in inflammatory bowel disease andstimulates cell motility and colony formation. Inflamm. Bowel. Dis. 16,795-803.

Al-Hajj, M., Wicha, M.S., ito-Hernandez, A., Morrison, S.J., Clarke, M.F., 2003.Prospective identification of tumorigenic breast cancer cells. Proc. Natl. Acad.Sci. U. S. A 100, 3983-3988.

Baron, J.A., et al., 2003. A randomized trial of aspirin to prevent colorectaladenomas. N. Engl. J. Med. 348, 891-899.

Boon, E.M., et al., 2004. Sulindac targets nuclear beta-catenin accumulation andWnt signalling in adenomas of patients with familial adenomatous polyposisand in human colorectal cancer cell lines. Br. J. Cancer 90, 224-229.

Bonnet, D., Dick, J.E. 1997. Human acute miyeloid leukemia is organized as a hierarchy that originates from a primitive hematopoietic cell. Nat Med 3(7);730-7.

Boulais, P.E., Frenette, P.S., 2015. Making sense of hematopoietic stem cell niches.Blood 125, 2621-2629.

Bowers, M., et al., 2015. Osteoblast ablation reduces normal long-term hematopoietic stem cell self-renewal but accelerates leukemia development. Blood 125, 2678-2688.

Brabletz, T., et al., 2005. Invasion and metastasis in colorectal cancer:epithelial-mesenchymal transition, mesenchymal-epithelial transition, stemcells and beta-catenin. Cells Tissues Organs 179, 56-65.

Brudvik, K.W., Paulsen, J.E., Aandahl, E.M., Roald, B., Tasken, K., 2011. Protein kinaseA antagonist inhibits beta-catenin nuclear translocation: c-Myc and COX-2expression and tumor promotion in $\mathrm{Apc}(\mathrm{Min} /+)$ mice. Mol. Cancer 10, 149.

Cadigan, K.M., Liu, Y.I. 2006. Wnt signaling: complexity at the surface. J Cell Sci. 119(Pt 3):395-402.

Castellone, M.D., Teramoto, H., Williams, B.O., Druey, K.M., Gutkind, J.S., 2005.Prostaglandin E2 promotes colon cancer cell growth through aGs-axin-beta-catenin signaling axis. Science 310, 1504-1510. 
Chen X., Yang J., Evans P.M., Liu C. 2008. Wnt signaling: the good and the bad. Acta Biochim Biophys Sin, 40(7); 577-94.

Dandekar, S., et al., 2014. Wnt inhibition leads to improved chemosensitivity inpaediatric acute lymphoblastic leukaemia. Br. J. Haematol. 167, 87-99.

De, M.C., et al., 2015. Dual cyclooxygenase and carbonic anhydrase inhibition bynonsteroidal anti-inflammatory drugs for the treatment of cancer. Curr. Med.Chem. 22, 2812-2818.

DuBois, R.N., Giardiello, F.M., Smalley, W.E., 1996. Nonsteroidal anti-inflammatorydrugs, eicosanoids, and colorectal cancer prevention. Gastroenterol. Clin. NorthAm. 25, 773-791.

Duchartrea, Y., KimaY., Kahn M., 2016. The Wnt signaling pathway in cancer. Critical Reviews in Oncology/Hematology 99, 141-149.

Espada, J., Moises, B.C., Prado, S.D., Medina, V. 2009. Wnt Signaling and Cancer Stem Cells. Clin Transl Oncol. 11;411-427.

Fleming, H.E., et al., 2008. Wnt signaling in the niche enforces hematopoietic stemcell quiescence and is necessary to preserve self-renewal in vivo. Cell Stem Cell2, 274-283.

Gang, E.J., et al., 2014. Small-molecule inhibition of CBP/catenin interactionseliminates drug-resistant clones in acute lymphoblastic leukemia. Oncogene33, 2169-2178.

Grandy, D., et al., 2009. Discovery and characterization of a small moleculeinhibitor of the PDZ domain of dishevelled. J. Biol. Chem. 284, 16256-16263.

Gurney, A., et al., 2012. Wnt pathway inhibition via the targeting of Frizzledreceptors results in decreased growth and tumorigenicity of human tumors.Proc. Natl. Acad. Sci. U. S. A 109, 11717-11722.

Han, J., et al., 2012. Small interfering RNA-mediated downregulation ofbeta-catenin inhibits invasion and migration of colon cancer cells in vitro. Med.Sci. Monit. 18, BR273-BR280.

Heidel, F.H., et al., 2012. Genetic and pharmacologic inhibition of beta-catenin targets imatinib-resistant leukemia stem cells in CML. Cell Stem Cell 10, 2-424.

Huang, S.M., et al., 2009. Tankyrase inhibition stabilizes axin and antagonizes Wntsignalling. Nature 461, 614620.Huels, D.J., et al., 2015. E-cadherin can limit the transforming properties ofactivating beta-catenin mutations. EMBO J. 34, 1-2333.

Huels, D.J., et al., 2015. E-cadherin can limit the transforming properties ofactivating beta-catenin mutations. EMBO J. 34, 1-2333.

Huelsken, J., Beh, Rens, J. 2002. The Wnt signalling pathway. J Cell Sci. 115(21);3977-8.

İlyas, M., 2005. Wnt signalling and the mechanistic basis of tumour development. J Pathol. 205(2);130-144.

Jamieson, C.H., Weissman, I.L., Passegue, E., 2004a. Chronic versus acutemyelogenous leukemia: a question of self-renewal. Cancer Cell 6, 1-533.

Jansen, S.R., et al., 2015. Prostaglandin E2 promotes MYCN non-amplifiedneuroblastoma cell survival via betacatenin stabilization. J. Cell Mol. Med. 19,210-226.

Kabiri, Z., et al., 2015. Wnts are dispensable for differentiation and self-renewal ofadult murine hematopoietic stem cells. Blood 126, 1086-1094.

Kadowaki, T., Wilder, E., Klingensmith, J., Zachary, K., Perrimon, N., 1996. Thesegment polarity gene porcupine encodes a putative multitransmembraneprotein involved in Wingless processing. Genes Dev. $10,3116-3128$. 
Kimelman, D., Xu, W., 2006. Beta-catenin destruction complex: insights andquestions from a structural perspective. Oncogene 25, 7482-7491.

Kirstetter, P., Anderson, K., Porse, B.T., Jacobsen, S.E., Nerlov, C., 2006. Activation ofthe canonical Wnt pathway leads to loss of hematopoietic stem cellrepopulation and multilineage differentiation block. Nat. Immunol. 7,1048-1056.

Klaus, A., Birchmeier, W., 2008. Wnt signalling and its impact on development andcancer. Nat. Rev. Cancer 8, 387-398.Klonisch, T., et al., 2008. Cancer stem cell markers in common cancerstherapeuticimplications. Trends Mol. Med. 14, 450-460.

Kode, A., et al., 2015. FoxO1-dependent induction of acute myeloid leukemia by osteoblasts in mice. Leukemia, 161, http://dx.doi.org/10.1038/leu.2015.

Kulak, O., et al., 2015. Disruption of Wnt/beta-catenin signaling and telomericshortening are inextricable consequences of tankyrase inhibition in humancells. Mol. Cell Biol. 35, 2425-2435.

Lai, S.L., Chien, A.J., Moon, R.T., 2009. Wnt/Fz signaling and the cytoskeleton:potential roles in tumorigenesis. Cell Res. 19, 532-545.Lane, S.W., et al., 2011. Differential niche and Wnt requirements during acutemyeloid leukemia progression. Blood 118, 2849-2856.

Lane, S.W., et al., 2011. Differential niche and Wnt requirements during acutemyeloid leukemia progression. Blood 118, 2849-2856.

Le, P.N., McDermott, J.D., Jimeno, A., 2015. Targeting the Wnt pathway in humancancers: therapeutic targeting with a focus on OMP-54F28. Pharmacol. Ther.146, 1-11.

Luis, T.C., Ichii, M., Brugman, M.H., Kincade, P., Staal, F.J., 2012. Wnt signalingstrength regulates normal hematopoiesis and its deregulation is involved inleukemia development. Leukemia 26, 414-421.

Madan, B., et al., 2015. Wnt addiction of genetically defined cancers reversed byPORCN inhibition. Oncogene.

Manabe, A., Coustan-Smith, E., Behm, F.G., Raimondi, S.C., Campana, D., 1992. Bonemarrow-derived stromal cells prevent apoptotic cell death in B-lineage acutelymphoblastic leukemia. Blood 79, 2370-2377.

Meads, M.B., Gatenby, R.A., Dalton, W.S., 2009. Environment-mediated drugresistance: a major contributor to minimal residual disease. Nat. Rev. Cancer 9,665-674.

Mikels, A.J, Nusse, R. 2006. Wnts as ligands: processing, secretion and reception. Oncogene 25(57):7461-8.

Moon, R.T., 2005. Wnt/beta-catenin pathway. Sci. STKE, cml.

Nusse, R. 2005. Wnt signaling in disease and in development. Cell Res 15(1) ;28-32.

Nusse, R., Varmus, H.E. 1992. Wnt genes. Cell. 69(7) ;1073-87.

Palmer, H.G., et al., 2001. Vitamin D(3) promotes the differentiation of coloncarcinoma cells by the induction of E-cadherin and the inhibition ofbeta-catenin signaling. J. Cell Biol. 154, 369-387.

Phillips, R.K., et al., 2002. A randomised, double blind, placebo controlled study ofcelecoxib, a selective cyclooxygenase 2 inhibitor, on duodenal polyposis infamilial adenomatous polyposis. Gut 50, 857-860.

Reya, T., Morrison, S.J., Clarke, M.F., Weissman, I.L., 2001. Stem cells, cancer, andcancer stem cells. Nature $414,105-111$.

Rios-Esteves, J., Resh, M.D., 2013. Stearoyl CoA desaturase is required to produceactive, lipid-modified Wnt proteins. Cell Rep. 4, 1072-1081.

Sandler, R.S., et al., 2003. A randomized trial of aspirin to prevent colorectaladenomas in patients with previous colorectal cancer. N. Engl. J. Med. 348,883-890. 
Schambony, A., Wedlich, D., 2007. Wnt-5A/Ror2 regulate expression of XPAPCthrough an alternative noncanonical signaling pathway. Dev. Cell 12, 779-792.

Schmitt, M., Metzger, M., Gradl, D., Davidson, G., Orian-Rousseau, V., 2015. CD44functions in Wnt signaling by regulating LRP6 localization and activation. CellDeath. Differ. 22, 677-689.

Schurch, C., Riether, C., Matter, M.S., Tzankov, A., Ochsenbein, A.F., 2012. CD27signaling on chronic myelogenous leukemia stem cells activates Wnt targetgenes and promotes disease progression. J. Clin. Invest. 122, 624-638.

Shulewitz, M., et al., 2006. Repressor roles for TCF-4 and Sfrp1 in Wnt signaling inbreast cancer. Oncogene 25 , 4361-4369.

Smith, et al., 2013. J. Clin. Oncol. 31 (suppl; abstr 2540).Steinbach, G., et al., 2000. The effect of celecoxib, a cyclooxygenase-2 inhibitor, infamilial adenomatous polyposis. N. Engl. J. Med. 342, 1946-1952.

Steinbach, G., et al., 2000. The effect of celecoxib, a cyclooxygenase-2 inhibitor, infamilial adenomatous polyposis. N. Engl. J. Med. 342, 1946-1952.

Teo, J.L., Kahn, M., 2010. The Wnt signaling pathway in cellular proliferation anddifferentiation: a tale of two coactivators. Adv. Drug Deliv. Rev. 62, 1149-1155.

Thun, M.J., Henley, S.J., Patrono, C., 2002. Nonsteroidal anti-inflammatory drugs asanticancer agents: mechanistic, pharmacologic, and clinical issues. J. Natl.Cancer Inst. 94, 252-266.

Valencia, A., et al., 2009. Wnt signaling pathway is epigenetically regulated bymethylation of Wnt antagonists in acute myeloid leukemia. Leukemia 23,1658-1666.

Van, A.R., Nusse, R., 2009. Towards an integrated view of Wnt signaling indevelopment. Development 136, 3205-3214.

Veeman, M.T., Axelrod, J.D., Moon, R.T., 2003. A second canon. Functions andmechanisms of beta-cateninindependent Wnt signaling. Dev. Cell 5, 367-377.

Wang, Y., et al., 2010. The Wnt/beta-catenin pathway is required for thedevelopment of leukemia stem cells in AML. Science 327, 1650-1653.

Willert, K., Jones, K.A., 2006. Wnt signaling: is the party in the nucleus? Genes Dev.20, 1394-1404.

Williams, J.L., et al., 2001. Nitric oxide-releasing nonsteroidal anti-inflammatorydrugs (NSAIDs) alter the kinetics of human colon cancer cell lines moreeffectively than traditional NSAIDs: implications for colon cancerchemoprevention. Cancer Res. 61, 3285-3289.

Williams, J.L., et al., 2004. NO-donating aspirin inhibits intestinal carcinogenesis inMin (APC(Min/+)) mice. Biochem. Biophys. Res. Commun. 313, 784-788.

Xiao, J.H., et al., 2003. Adenomatous polyposis coli (APC)-independent regulationof beta-catenin degradation via a retinoid X receptor-mediated pathway. J.Biol. Chem. 278, 29954-29962.

Yamada, T., et al., 2000. Transactivation of the multidrug resistance 1 gene byT-cell factor 4/beta-catenin complex in early colorectal carcinogenesis. CancerRes. 60, 4761-4766.

Yamamoto, S., et al., 2008. Cthrc1 selectively activates the planar cell polaritypathway of Wnt signaling by stabilizing the Wnt-receptor complex. Dev. Cell15, 23-36.

Yang, K., et al., 2003. Regional response leading to tumorigenesis after sulindac insmall and large intestine of mice with Apc mutations. Carcinogenesis 24,605-611.

Zhang, B., et al., 2013. Microenvironmental protection of CML stem and progenitorcells from tyrosine kinase inhibitors through N-cadherin andWnt-beta-catenin signaling. Blood 121, 1824-1838. 